\title{
Inhibition of the Chemiluminescence and Chemotactic Activity of Phagocytes for Selected Ficus Species Extract and Their Lipoxygenase and Xanthine Oxidase Enzyme Inhibitory \\ (Perencatan Aktiviti Kemiluminesens dan Kemotaktik Fagosit oleh Ekstrak Spesies Ficus Terpilih dan Kesan Perencatan terhadap Enzim Lipoksigenase dan Xantina Oksidase)
}

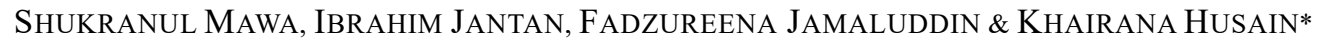

\section{ABSTRACT}

The effects of crude methanol from seven Ficus species on reactive oxygen species (ROS) production were evaluated using luminol based chemiluminescence assay and their inhibition of PMNs chemotaxis was investigated using Boyden chamber technique. Crude methanol of F. aurantiaca, F. parietalis, and F. annulata showed strong activity against $P M N$ chemotaxis with $I C_{50}$ values of $1.4,0.3$ and $2.2 \mu \mathrm{g} / \mathrm{mL}$, respectively, while crude methanol from $\mathrm{F}$. aurantiaca and F. parietalis on whole blood and ROS production of PMNs exhibited high inhibitory activity for luminol enhanced chemiluminescence with $I C_{50}$ values of $1.4,0.9$, and 1.0, $0.4 \mu \mathrm{g} / \mathrm{mL}$, respectively. In xanthine oxidase inhibition assay, crude methanol from F. aurantiaca (stem), F. parietalis (stem), and F. annulata (leaf) exhibited greater than $92 \%$ inhibition at concentration of $100 \mu \mathrm{g} / \mathrm{mL}$ (with $I C_{50}$ values of $0.9,1.0$ and $8.9 \mu \mathrm{g} / \mathrm{mL}$, respectively) while some extracts of other species showed more than $60 \%$ inhibitions at this concentration. In soybean lipoxygenase (SBL) assay, the methanolic extracts of these 3 species showed potent $S B L$ inhibition with $I C_{50}$ values of $0.3,0.7$, and $6.3 \mu \mathrm{g} / \mathrm{mL}$, respectively. The overall results suggest that F. parietalis, F. annulata, and F. aurantiaca might be a prospective source of anti-inflammatory mediators and as a source of new immunomodulatory agents.

Keywords: Chemiluminescence; chemotaxis; medicinal plants; soybean lipoxygenase enzyme; xanthine oxidase

ABSTRAK

Kesan ekstrak mentah metanol terhadap tujuh spesies Ficus ke atas penghasilan spesies oksigen teraktif(ROS) telah dinilai dengan menggunakan assai kemiluminesens yang berasaskan luminol dan perencatan PMN kemotaxis pula menggunakan teknik kebuk Boyden. Ekstrak mentah metanol F. aurantiaca, F. parietalis dan F. annulata menunjukkan aktiviti yang kuat terhadap PMN kemotaxis dengan nilai masing-masing $I C_{50} 1.4,0.3$ dan $2.2 \mu \mathrm{g} / \mathrm{mL}$, manakala ekstrak mentah metanol daripada F. aurantiaca dan F. parietalis terhadap keseluruhan darah dan penghasilan ROS ke atas PMN pula menunjukkan kesan perencatan yang tinggi terhadap kemiluminesens bagi luminol dengan nilai masing-masing $I C_{50}$ 1.4, 0.9 dan 1.0, $0.4 \mu \mathrm{g} / \mathrm{mL}$. Ekstrak mentah metanol F. aurantiaca (batang), F. parietalis (batang) dan F. annulata (daun) dalam asai xantina oksidase menunjukkan perencatan lebih tinggi daripada $92 \%$ pada kepekatan $100 \mu \mathrm{g} / \mathrm{mL}\left(I C_{50}\right.$ 0.9, 1.0 dan $8.9 \mu \mathrm{g} / \mathrm{mL}$, masing-masing) manakala sebahagian ekstrak spesies lain pula menunjukkan perencatan yang lebih tinggi daripada $60 \%$ pada kepekatan tersebut. Asai lipoksigenase soya (SBL) pula, ekstrak mentah metanol daripada ketiga-tiga spesies ini menunjukkan perencatan SBL yang kuat dengan nilai masing-masing $I C_{50} 0.3,0.7$ dan $6.3 \mu \mathrm{g} / \mathrm{mL}$. Hasil kajian ini mencadangkan bahawa ekstrak mentah metanol daripada F. parietalis, F. annulata dan F. aurantiaca berkemungkinan dapat dibangunkan sebagai sumber perantara anti-inflamasi dan agen imunomodulasi yang baru.

Kata kunci: Enzim lipoksigenase soya; kemiluminesens; kemotaxis; tumbuhan ubatan; xantina oksidase

\section{INTRODUCTION}

Phagocytes play an important role in one's innate immune system defence mechanism. It serves as an important link between adaptive and innate immune mechanisms. Polymorphonuclear phagocytes (often called neutrophils or PMNs) are an important group of phagocytes. Neutrophils constitute a majority of blood leucocytes and develop from early precursors as monocytes and macrophages.
During the phagocytosis, an increasing glucose and oxygen consumption is seen, which is referred to as the respiratory burst. The consequence of respiratory burst is a number of oxygen-containing compounds, which kill the phagocytosed bacteria during respiratory burst. Based on the types of superoxide produced, the destruction of microorganisms can be divided into two categories, namely destruction by reactive oxygen species and destruction by reactive nitrogen species (Hiyoshi et al. 2018). 
Chemotaxis is the migration of phagocytic cells towards chemical signals emitted at the site of injury. The phagocytic cells are recruited to the site of infection or tissue damage by certain chemical stimuli that act as chemoattractants. They include the products of microorganisms, phospholipids released by injured mammalian cells, and the complement component C5a (Lee et al. 2019). Immunomodulators and antiinflammatory drugs are widely used as the inhibitors of phagocyte reactive oxygen species (ROS) production in order to treat a variety of disorders along with inflammation. Therefore, the innovation of a novel plant with immune system-modulating activities has become a progressively important area of research, particularly in the search for new-generation vaccine adjuvant.

Xanthine oxidase (XO) serves as a significant biological foundation of oxygen-derived free radicals, which yields oxidative break to living tissues implicated in many pathological processes such as inflammation, atherosclerosis, cancer, and ageing (Xinglong et al. 2018). It is the enzyme responsible for the formation of uric acid from the purines, namely hypoxanthine, and xanthine, and is responsible for a medical condition known as gout due to their overproduction. Since xanthine oxidase inhibitors (XOI) have minor side effects in contrast with other anti-inflammatory mediators such as uricosuric, it is greatly efficient for inflammation. The clinically used XOI is only allopurinol and causes various side effects, namely hypersensitivity syndrome, Stevens-Johnson syndrome, and renal toxicity. Although it is usually known to be safe, some contraindications are applicable for approximately $2 \%$ of the general population. This is a prominent fact, leading researchers to search for novel XOIs among natural products. Until now, phenolics and particular flavonoids have been found to be a large number of chemical skeletons with XO inhibitory properties, and their functions have been methodically evaluated (Liu et al. 2017; Yang et al. 2019). Therefore, the exploration of novel XOIs from natural plants may be helpful for the treatment of gout and a variety of inflammatory illnesses.

5-Lipoxygenase enzyme (5-LOX), 12-lipoxygenase enzyme (12-LOX), and 15-lipoxygenase enzyme (15LOX) are a family of enzymes called lipoxygenase (LOX). The catalysation of 5-LOX synthesizes fatty acid signal molecules leukotrienes from arachidonic acid in the cell. The overproduction of leukotrienes causes a reduction in the soft muscle's inside layer, which is the source of inflammation such as asthma and allergic diseases. Furthermore, hypersensitive inflammatory reactions like asthma, ulcerative colitis, rheumatoid arthritis, psoriasis, glomerular nephritis, and cancer are brought out by these arachidonic acid metabolites. The 5-LOX enzyme is a soybean lipoxygenase (SBL) similar to human LOX, which further catalyses the oxidation of linoleic acid, arachidonic acid, and other unsaturated fatty acids. Consequently, the SBL inhibition test may be applied to find new material that is actively functioning as the inhibitors of mammalian lipoxygenases; an instance is 5-LOX (Srivastava et al. 2016).

Ficus (Moraceae) comprises one of the largest genera of angiosperms with more than 800 species of trees, shrubs, hemi-epiphytes, and climbers in the tropics and subtropics worldwide. It is traditionally used for the treatment of wound healing, headache, toothache, and inflammation. A number of Ficus species are wellknown in Asia as medicinal plants and widely used in folk medicine for the treatment of flu, malaria, tonsillitis, bronchitis, rheumatism, and various inflammatory diseases (Burkill 1966). One of the most biologically active species of Ficus is F. carica, which has many uses according to different ethnopharmacological reports (Mawa et al. 2013). In Malaysia, Ficus has been traditionally used for the treatment of inflammation, headache, wound, and toothache (Kamaruddin \& Latif 2002). It is widespread in the lowland forests of Kelantan, Terengganu, Perak, Pahang, Selangor, Melaka, and Johor. Malaysia has a large number of medicinal plants and some plants have been used to treat gout; however, until now, no traditional usage of Ficus has been reported. In this study, seven species of Ficus from Malaysian therapeutic plants have been chosen to screen their XO inhibitory action based on the ethnomedical uses of the genus in various inflammatory disorders, such as rheumatism, swellings, and hyperglycaemia (Khajuria et al. 2017; Yang et al. 2018).

\section{MATERIALS AND METHODS}

\section{PLANT SAMPLES}

The stem $(500.0 \mathrm{~g})$ and leaf $(4.5 \mathrm{~kg})$ of $F$. aurantiaca Griff. (SM 2109), leaf (2.3 kg) of $F$. grossularioidae Burm. F. (SM2110), leaf (5.1 kg) of F. obscura Blume. (SM2133), leaf $(4.9 \mathrm{~kg})$ of $F$. heteropleura Blume. (SM2130), leaf (3.6 kg) of F. annulata Blume. (SM2131), stem $(300.2 \mathrm{~g})$ and leaf $(3.5 \mathrm{~kg})$ of $F$. parietalis Blume. (SM2132) and leaf of $F$. bengalgensis L. (SM2133) were collected from Banting, Selangor, Malaysia. The voucher specimens were identified and deposited at the Herbarium of Universiti Kebangsaan Malaysia (UKM), Bangi.

\section{PREPARATION OF PLANT EXTRACT}

Each plant material was air-dried at room temperature and ground. The ground powders of the stem (100.0 g) and leaf (132.1 g) of $F$. aurantiaca, leaf (57.5 g) of F. grossularioidae Burm. F, leaf (150 g) of F. obscura Blume, leaf (140.0 g) of $F$. heteropleura Blume, stem $(50.0 \mathrm{~g})$ and leaf $(100.0 \mathrm{~g})$ of $F$. parietalis Blume, leaf $(100.0 \mathrm{~g})$ of $F$. annulata Blume, and leaf $(100.0 \mathrm{~g})$ of $F$. bengalgensis L. were macerated with methanol (1:3 $\mathrm{m} / \mathrm{v}$ ) every three days and filtration was repeated three 
times. The extract was evaporated to remove the solvent by using a rotary evaporator in order to obtain a crude extract.

\section{CHEMICALS, REAGENTS AND EQUIPMENTS}

Luminol, serum opsonised zymosan A, phosphate buffer saline (PBS), Hanks balanced salt solutions (HBSS) ${ }^{++}$, Ficoll, dextran, dimethylsulfoxide (DMSO), $N$-formylmethionyl-leucyl-phenylalanine (fMLP), hematoxyline, oil immersion, trypan blue, aspirin and ibuprofen were purchased from Sigma (St Louis, Missouri, USA). Chemicals for xanthine oxidase and soybean lipoxygenage enzyme inhibition assay: Xanthine oxidase (XO) enzyme from cow's milk (20 units/mL) was obtained from Roche Diagnostics Pt. Ltd. (Cat No. 10110434001, St. Louis, MI, USA). Lipoxygenase enzyme, type 1B, soybean ( 80 units/well) was obtained from Sigma (Cat No. L-73951, St. Louis, MI, USA) while xanthine substrate $(0.15 \mathrm{mM})$, allopurinol and phosphate buffer $\left(\mathrm{KH}_{2} \mathrm{PO}_{4} 50 \mathrm{mM}, \mathrm{pH} 7.5\right)$, substrate linoleic acid (0.3 mM, Sigma cat no. L-8134, FW 302.4), DMSO, phosphate buffer $\left(\mathrm{NaH}_{2} \mathrm{PO}_{4} 100 \mathrm{mM}\right.$, $\mathrm{pH}$ 8.0) and phenidone were obtained from Sigma (St. Louis, MI, USA). All other chemicals have been used in this research were got hold of commercially and were of analytical grade. The working solution of substrate xanthine in buffer ( $\mathrm{pH} 7.5)$, the xanthine oxidase enzyme solution (0.2 unit/ well) in buffer $(\mathrm{pH} 7.5)$ and the working solution of substrate linoleic acid in phosphate buffer ( $\mathrm{pH} 8.0$ ), the soybean lipoxygenase (SBL) enzyme solution (80 unit/well) in buffer $(\mathrm{pH} \mathrm{8.0)}$ ) were prepared immediately before use.

While chemiluminescence measurements were carried out on a Luminoscan Ascent luminometer (Thermo Scientific, UK). A Boyden chamber (48-well) with $2 \mu \mathrm{m}$ polycarbonate membrane filter separating the upper and lower compartments was purchased from Neuro probe, Cabin Jhon, MD, USA), carbon dioxide incubator (Thermo scientific, UK), Haemocytometer (Hausser Scientific, USA and low-power microscope (Olympus, Germany) were also used in this assay.

ISOLATION OF POLYMORPH NUCLEAR LEUCOCYTES (PMNS) Human blood was collected from a healthy volunteer who had fasted for at least $8 \mathrm{~h}$. PMNs were isolated by Ficoll gradient separation method as described (Yuandani et al. 2013). The use of human blood in this study was approved by the human ethics committee of Universiti Kebangsaan Malaysia Medical Centre (HUKM), Cheras, with a recorded permission number of FF-220-2008. Cell counts were performed using a haemocytometer.

\section{CELL VIABILITY}

Cell viability test was carried out using trypan blue dye exclusion method with additional procedure modification as described by Koko et al. (2008). The neutrophils $\left(1 \times 10^{6} / \mathrm{mL}\right)$ were incubated with $6.25 \mu \mathrm{g} / \mathrm{mL}$ and $100 \mu \mathrm{g} / \mathrm{mL}$ of plants extracts in triplicate at $37^{\circ} \mathrm{C}$ for 1 to $2 \mathrm{~h}$. In the chemotaxis assay, the lowest concentration of $6.25 \mu \mathrm{g} / \mathrm{mL}$ and the highest concentration of 100 $\mu \mathrm{g} / \mathrm{mL}$ were utilised. Cell death was indicated by the blue dye uptake anhe percentage of cell viability was considered from the total cell counts.

\section{CHEMILUMINESCENCE ASSAY}

Luminol enhanced chemiluminescence assay was carried out using a modified version of the described method (Mawa et al. 2016; Yuandani et al. 2013). In brief, $25 \mu \mathrm{L}$ of human whole blood or $25 \mu \mathrm{L}$ of isolated PMN cells were suspended in HBSS $^{++}$into each well of 96-well microplate. The plate was incubated with $25 \mu \mathrm{L}$ of tested samples and aspirin at five different concentrations $(12.5,6.25,3.18,1.56$, and $0.78 \mu \mathrm{g} / \mathrm{mL})$ of each sample for $50 \mathrm{~min}$ at $37{ }^{\circ} \mathrm{C}$ in luminoscan, while $25 \mu \mathrm{L}$ of $\mathrm{HBSS}^{++}$was used as for the negative control. The cells were induced with $25 \mu \mathrm{L}$ of Serum Opsonised Zymosan, followed by $25 \mu \mathrm{L}$ of luminol into each well. Then, the $\mathrm{HBSS}^{++}$solution was added into each well to ensure the final volume of $200 \mu \mathrm{L}$. Aspirin was used as the positive control while the negative control contained zymosan, luminol, DMSO $(0.5 \%), \mathrm{HBSS}^{++}$, and cells. The percentage of inhibition was calculated by the measurement of RLU (reading luminometer unit) of peak and total integral values, with repeated scans conducted.

\section{CHEMOTAXIS ASSAY}

The assay was carried out using the modified 48-well Boyden chamber method (Yuandani et al. 2016). The Boyden chamber contains 48 wells with a diameter of $8 \mu \mathrm{m}$ and is divided into two compartments by a filter separation. In brief, $25 \mu \mathrm{L}$ of chemoattractant, fMLP (10-8 $\mathrm{M}$, diluted with chemoattractant buffer solution) was added to the lower compartment of the Boyden chamber. Then, $45 \mu \mathrm{L}$ of PMN cell suspension with 5 $\mu \mathrm{L}$ of test samples and ibuprofen at five concentrations $(6.25,12.5,25,50$, and $100 \mu \mathrm{g} / \mathrm{mL})$ were added to the upper compartment of the chamber, whereas the negative control contained $45 \mu \mathrm{L}$ of PMN cell suspension and $5 \mu \mathrm{L}$ of chemoattractant buffer. Ibuprofen was used as a positive control. The final concentrations of test samples and ibuprofen in the wells were $0.625,1.25$, $2.5,5$, and $10 \mu \mathrm{g} / \mathrm{mL}$. The chamber was incubated in $5 \%$ carbon dioxide incubator for $1 \mathrm{~h}$ at $37{ }^{\circ} \mathrm{C}$. After incubation, the polycarbonate membrane (where the migrated cells remained) was stained with PBS, methanol $(99.5 \%)$, haematoxylin, distilled water, ethanol $(70 \%$ and $95.8 \%$ ) and xylene. The distance of cell migration was measured using a low power microscope with $40 \mathrm{x}$ magnifications.

\section{In vitro XANTHINE OXIDASE INHIBITION ASSAY}

All extracts were investigated for in vitro XO inhibitory activity and the assay was run spectrophotometrically in an aerobic environment (Mamat et al. 2014). The 
combination for the assay was prepared with $1 \mathrm{~mL}$ of test solutions $(6.25,12.5,25,50$, and $100 \mu \mathrm{g} / \mathrm{mL}), 2.9 \mathrm{~mL}$ of phosphate buffer ( $\mathrm{pH} 7.5$ ), and $0.1 \mathrm{~mL}$ of enzyme solution (0.01 units $/ \mathrm{mL}$ in phosphate buffer, $\mathrm{pH}$ 7.5). They were made instantly before use. After pre-incubation for 15 $\min$ at $25{ }^{\circ} \mathrm{C}$, the reaction was started by adding $2 \mathrm{~mL}$ of substrate solution (i.e. $0.15 \mathrm{mM}$ xanthine in phosphate buffer). The mixture was incubated for $30 \mathrm{~min}$ at $25{ }^{\circ} \mathrm{C}$ and the reaction was then blocked by adding $1 \mathrm{~mL}$ of $1 \mathrm{~N}$ hydrochloric acid, whereby its absorbance was calculated at $295 \mathrm{~nm}$ with a UV spectrophotometer. In the same way, a blank was arranged but the enzyme solution was replaced with phosphate buffer. Another reaction mixture was prepared (control) and had $100 \mu \mathrm{L}$ of DMSO instead of test samples in order to generate the maximum uric acid formation. The reading was taken with three parallel measurements and the assay was done in triplicate. The total amount of enzyme necessary to make $1 \mathrm{mmol}$ of uric acid per min at $25{ }^{\circ} \mathrm{C}$ was thus defined as one unit of xanthine oxidase (XO). Xanthine oxidase inhibitory activity was calculated to evaluate the degree of inhibitory activity using a reported equation (Xinglong et al. 2018). Allopurinol as a recognised inhibitor of XO has been used as a positive control, while the $\mathrm{IC}_{50}$ values have been considered from the mean values of data.

$$
\text { Percentage of inhibition }(\%)=(1-\beta / \alpha) \times 100
$$

where $\alpha$ is the optical density of control or $\alpha$ is the activity of XO without plant extract, and $\beta$ is the optical density of test samples or $\beta$ is the activity of $\mathrm{XO}$ with plant extract.

\section{In vitro SOYBEAN LIPOXYGENASE ENZYME INHIBITION ASSAY}

Soybean lipoxygenase (SBL) inhibition was evaluated spectrophotometrically with the measurement of change in the absorbance at $234 \mathrm{~nm}$ following the modified published method (Zhang et al. 2018). The structure of hydroperoxylinoleic acid was then converted to linoleic acid. The blank, control and samples were made with the following compositions:

Blank: $700 \mu \mathrm{L}$ of sodium phosphate buffer (100 $\mathrm{mM}, \mathrm{pH} 8.0$ ) was put into $50 \mu \mathrm{L}$ of DMSO solution and $250 \mu \mathrm{L}$ of linoleic acid $(250 \mu \mathrm{M}$ solution in phosphate buffer) was added to formulate the $1 \mathrm{~mL}$ volume of reaction.

Control: Sodium phophate buffer $(200 \mu \mathrm{L}, 100 \mathrm{mM})$ was added to DMSO $(50 \mu \mathrm{L})$ solution, enzyme $(500 \mu \mathrm{L}$, 400 units/mL in phosphate buffer), and linoleic acid (250 $\mu \mathrm{L}, 250 \mu \mathrm{M})$ to make the $1 \mathrm{~mL}$ volume of reaction.

Sample: Sodium phosphate buffer $(200 \mu \mathrm{L}, \mathrm{pH} 8.0)$ was added to $50 \mu \mathrm{L}$ of extracts at various concentrations (6.25-100 $\mu \mathrm{g} / \mathrm{mL}$ in DMSO), enzyme (500 $\mu \mathrm{L}, 400$ unit/ $\mathrm{mL}$ in phosphate buffer), and linoleic acid $(250 \mu \mathrm{L})$ to make the volume of reaction $1 \mathrm{~mL}$.
Phenidone was used as a standard SBL inhibitor. Each experiment was done in triplicates.

Percentage of inhibition was considered using the following formula:

$\%$ of inhibition $=($ Absorbance of control-Absorbance of sample/Absorbance of control) $\times 100$

\section{STATISTICAL ANALYSIS}

Data were analyzed using One-way ANOVA, post hoc, Turkey. $\mathrm{P}<0.05$ was considered to be statistically significant using SPSS 17.0 statistical software. All values were characterized as mean \pm S.E.M. Probit programme was used to determine the $\mathrm{IC}_{50}$ values for active samples.

\section{RESULTS AND DISCUSSION}

\section{REACTIVE OXYGEN SPECIES (ROS) INHIBITORY ACTIVITY OF CRUDE EXTRACTS ON HUMAN WHOLE BLOOD AND PMNS}

This study used different parts of varying species. Different plant parts may contain different chemical constituents, thus each part will show different activities for the same assay. Screening the extracts from seven Ficus species on whole blood showed that the crude methanol of $F$. aurantiaca (stem), $F$. parietalis (stem), and $F$. annulata (leaf) exhibited significant inhibition for luminol-enhanced chemiluminescence with $\mathrm{IC}_{50}$ values of $1.4,0.9$ and $6.1 \mu \mathrm{g} / \mathrm{mL}$, respectively (Table 1). In contrast, the first two were lower than that of the positive control, namely aspirin $(2.1 \mu \mathrm{g} / \mathrm{mL})$. The highest percentage of inhibition on whole blood was shown by the crude extract of $F$. aurantiaca stem. The crude extracts were further evaluated for their effects on the oxidative burst of PMNs. Among all extracts, crude methanol of five species showed inhibition on PMNs, whereas crude methanol of $F$. aurantiaca (stem), $F$. parietalis (stem), and $F$. annulata (leaf) showed the most potent activity against PMNs with the $\mathrm{IC}_{50}$ values of 1.0, 0.4 and $4.1 \mu \mathrm{g} / \mathrm{mL}$, respectively. The $\mathrm{IC}_{50}$ values were lower than that of the positive control aspirin $(1.7 \mu \mathrm{g} /$ $\mathrm{mL}$ ) (Table 1). The activation of phagocytosis by serum opsonised zymosan marks the simultaneous production of ROS and the release of hydrolytic enzymes. The process was initiated by the reaction of ROS on the surface of phagocytic cells. The released ROS were then measured by luminol-enhanced chemiluminescence assay. Luminol increases in detecting the specific ROS affected by the extracts because luminol can enter the cells due to its small molecular weight, and then react with intracellular and extracellular ROS (Hiyoshi 2018). The dose-dependent effects of active extracts are shown in Figure 1(a) and 1(b). 


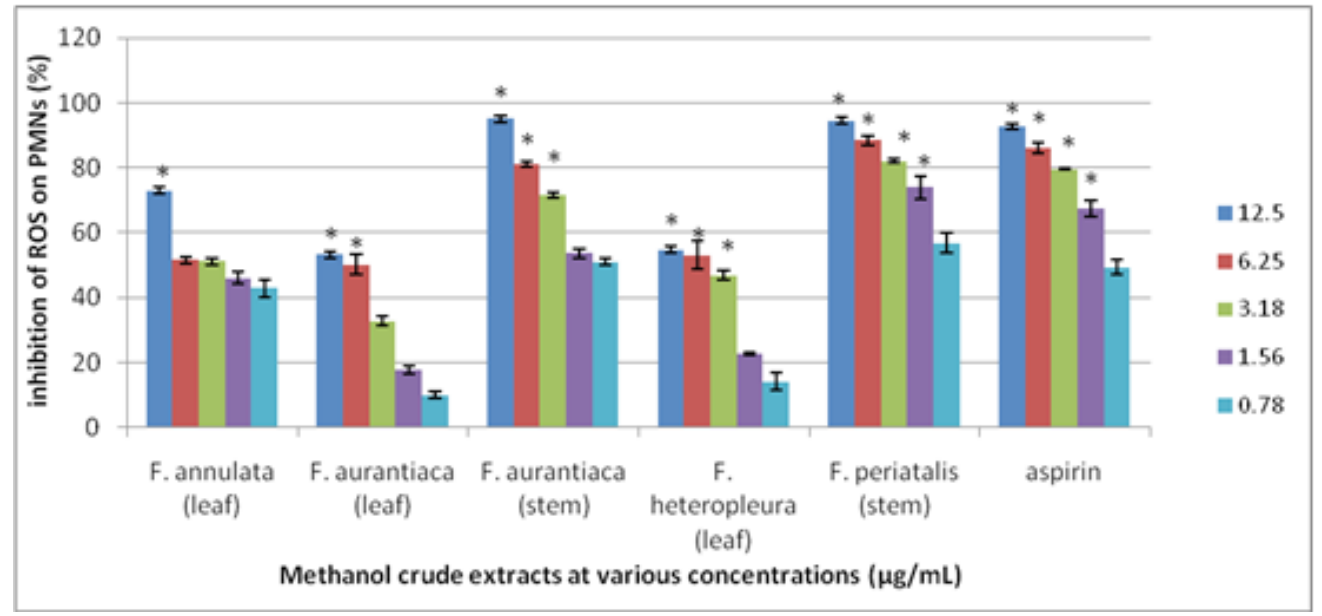

FIGURE 1(a). Dose dependent percentage of inhibition of ROS inhibitory activities of active crude methanol on isolated PMNs assayed by luminol amplified chemiluminescence

Data are mean $\pm \operatorname{SEM}(n=3),{ }^{*} P<0.05$ is significant difference compared to the negative control

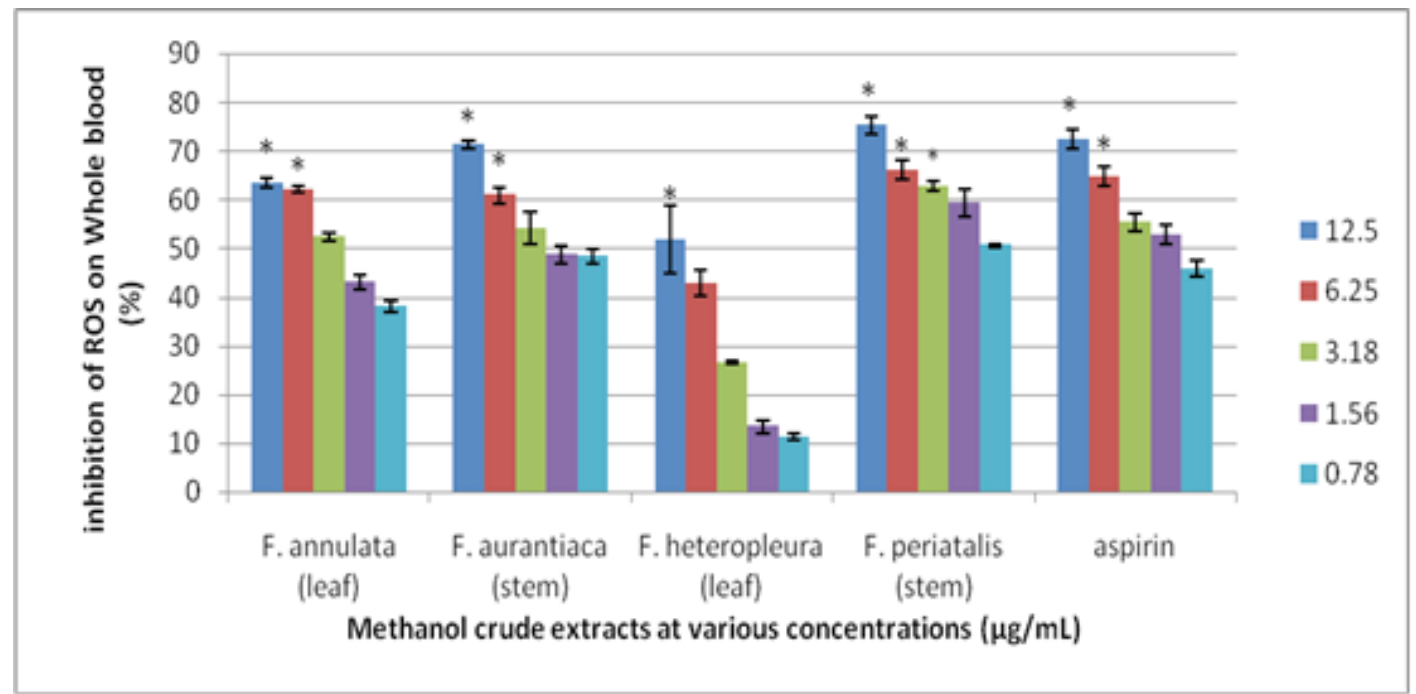

FIGURE 1(b). Dose dependent percentage of inhibition of ROS inhibitory activities of active crude methanol on human whole blood assayed by luminol amplified chemiluminescence

Data are mean $\pm \operatorname{SEM}(n=3)$. ${ }^{*} P<0.05$ is significant difference compared to the negative control

\section{CHEMOTACTIC ACTIVITY}

Cells were viable $(>95 \%)$ at the concentration of 6.25 and $100 \mu \mathrm{g} / \mathrm{mL}$ of the extracts after incubation of $2 \mathrm{~h}$. Of all the extracts of seven species, $F$. aurantiaca (stem), $F$. parietalis (stem), and $F$. annulata (leaf) showed strong inhibitory activity with dose-dependent effects on the migration of PMNs towards the chemoattractant (fMLP) with $\mathrm{IC}_{50}$ values of 1.4 and $0.3 \mu \mathrm{g} / \mathrm{mL}$, respectively. $F$. bengalgensis also inhibited the migration of PMNs. The $\mathrm{IC}_{50}$ values of $F$. aurantiaca $(1.4 \mu \mathrm{g} / \mathrm{mL})$ and $F$. parietalis $(0.3 \mu \mathrm{g} / \mathrm{mL})$ were lower than that of positive control ibuprofen $(1.5 \mu \mathrm{g} / \mathrm{mL})$. The cell viability test was performed using trypan blue to determine the toxicity of concentrations for all plant extracts. The elevated cell viability indicated that the extracts were nontoxic to immune cells and could highly adapt the cellular immune response in the reaction mixtures. Chemotractant buffer (DMSO and HBSS, 1:1 ratio) was used as a control and ibuprofen, which was found to be the most effective drug in a study to determine the effect of selected NSAIDs in blocking the migration of PMNs (Lee et al. 2019). The percentage of inhibitions (\%) and the $\mathrm{IC}_{50}$ values of active extracts with dose-dependent effects are shown in Figure 2 and Table 1 , respectively. 


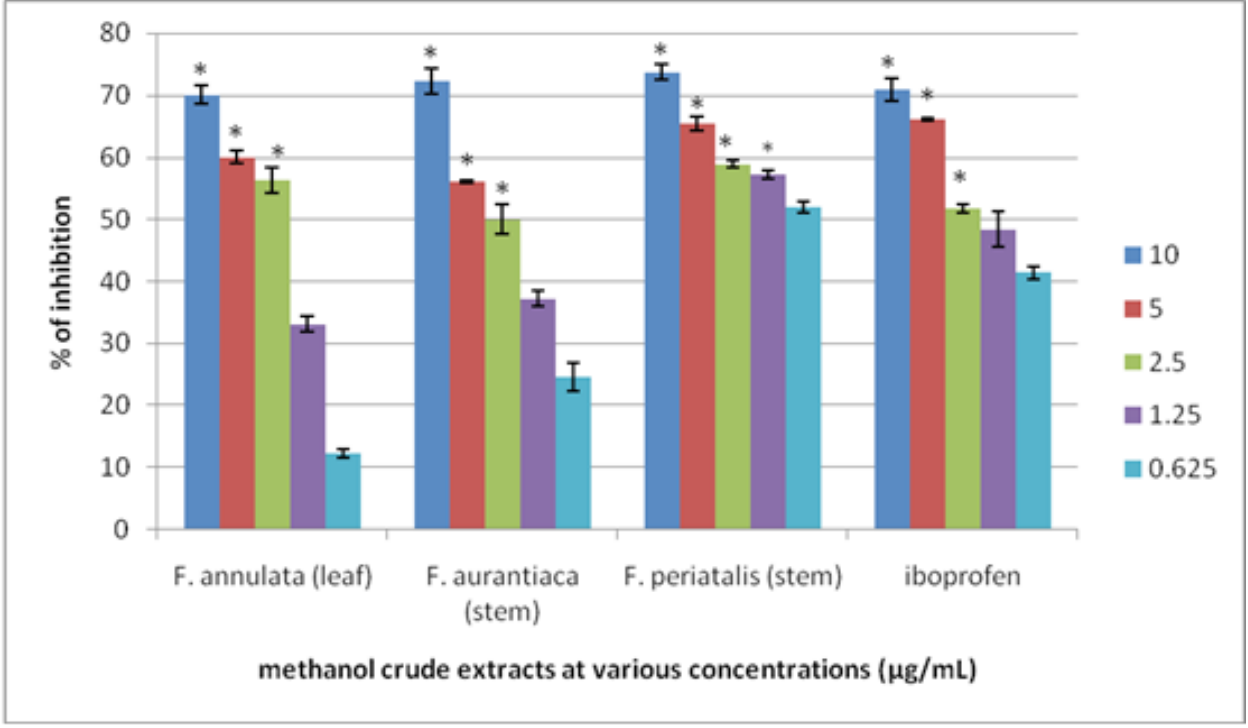

FIGURE 2. Dose dependent percentage of inhibition on PMNs chemotaxis

Data are mean $\pm \operatorname{SEM}(n=3) .{ }^{*} P<0.05$ is significant difference compared to the negative control

TABLE 1. IC f $_{50}$ values of active crude methanol and positive control for chemiluminescence and chemotaxis activity. Data represents mean $\pm \operatorname{SEM}(n=3)$ in triplicate measurement

\begin{tabular}{|c|c|c|c|c|}
\hline \multirow[t]{3}{*}{ Plant species } & \multirow[t]{3}{*}{ Parts } & \multicolumn{3}{|c|}{$\mathrm{IC}_{50}$ value $\pm \operatorname{SEM}(\mu \mathrm{g} / \mathrm{mL})$} \\
\hline & & \multicolumn{2}{|c|}{ Chemiluminescence } & \multirow[t]{2}{*}{ Chemotaxis } \\
\hline & & PMNs & WB & \\
\hline F. anuulata & leaf & $4.1 \pm 1.5$ & $6.1 \pm 1.1$ & $2.2 \pm 0.3$ \\
\hline F. aurantiaca & leaf & $17.1 \pm 1.1$ & - & - \\
\hline F. aurantiaca & stem & $1.0 \pm 0.3$ & $1.4 \pm 0.7$ & $1.4 \pm 0.4$ \\
\hline F. parietalis & stem & $0.4 \pm 0.07$ & $0.9 \pm 0.7$ & $0.3 \pm 0.1$ \\
\hline F. heteropleura & leaf & $15.3 \pm 1.2$ & $20.8 \pm 3.4$ & - \\
\hline F. grossularioidae & leaf & - & - & - \\
\hline F. bengalgensis & leaf & - & - & - \\
\hline F. obscura & leaf & - & - & - \\
\hline $\begin{array}{l}\text { Aspirin } \\
\text { (positive control) }\end{array}$ & - & $1.7 \pm 0.3$ & $2.1 \pm 0.9$ & - \\
\hline $\begin{array}{l}\text { Iboprufen } \\
\text { (positive control) }\end{array}$ & - & - & - & $1.5 \pm 0.3$ \\
\hline
\end{tabular}




\section{In vitro XANTHINE OXIDASE INHIBITORY ACTIVITY}

Of the 11 crude extracts of different parts from seven species screened in this study, five extracts demonstrated XO inhibition at the concentration of $100 \mu \mathrm{g} / \mathrm{mL}$, whereas three extracts showed more than $92 \%$ inhibition at this concentration. Four crude extracts showed more than $50 \%$ inhibitory activity at the lowest concentration of $6.25 \mu \mathrm{g} / \mathrm{mL}$. Among the extracts screened for XO inhibition, the methanolic extracts from the stem of $F$. aurantiaca and $F$. parietalis and leaf of $F$. annulata showed the highest inhibitory activity with $\mathrm{IC}_{50}$ values of 0.9 and 1.0 and $8.9 \mu \mathrm{g} / \mathrm{mL}$, respectively. Any crude extracts of $F$. grossolarioidae $F$. heteropleura, and $F$. obscura did not exhibit any important activity up to 100 $\mu \mathrm{g} / \mathrm{mL}$ concentrations while $F$. bengalgensis showed more than $60 \%$ inhibition only at a concentration of $100 \mu \mathrm{g} / \mathrm{mL}$. Finally, the methanolic extracts of $F$. parietalis (stem), F. aurantiaca (stem), and $F$. annulata (leaf) exhibited potent xanthine oxidase inhibition that is comparable to that of positive control allopurinol. Allopurinol was used as a standard drug to compare the studied results, which showed a $92.5 \%$ inhibitory activity at a concentration of $100 \mu \mathrm{g} / \mathrm{mL}$ at the $\mathrm{IC}_{50}$ value of $0.96 \mu \mathrm{g} / \mathrm{mL}$. The methanolic extracts of $F$. aurantiaca (stem), and $F$. parietalis (stem) exhibited greater than $92 \%$ inhibitory activity, which was higher than that of allopurinol. Many published literature have shown different anti-inflammatory and antioxidant properties of various species of Ficus (Yang et al. 2018) due to the existence of flavonoids, triterpenoids, lignans, alkaloid, diterpene, phenolics, and polyphenols (Cheng et al. 2019; Mawa et al. 2016). Accordingly, XO inhibitory activity of the extracts from the studied species of Ficus might be credited to the existence of active chemical constituents against inflammation. The percentage of inhibitions (\%) and $\mathrm{IC}_{50}$ values of active extracts with dose-dependent effects are shown in Figure 3 and Table 2, respectively.

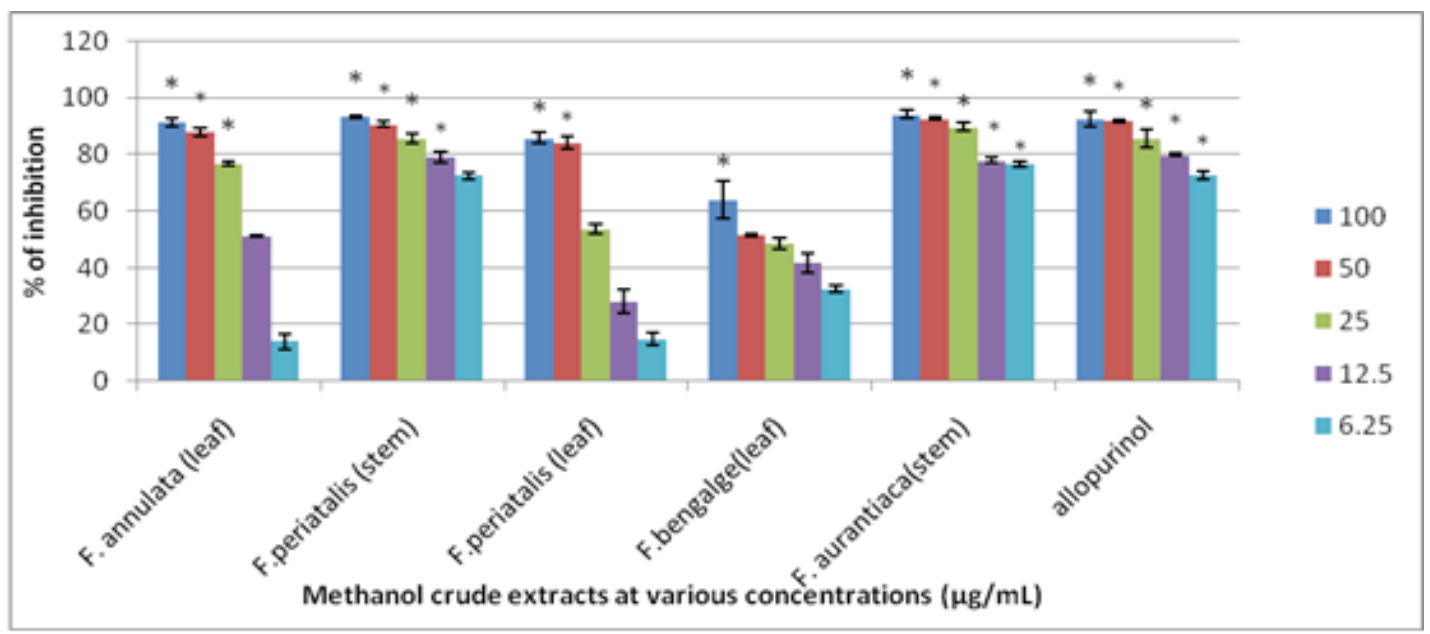

FIGURE 3. Xanthine oxidase inhibitory effects of active crude methanol

Data are mean $\pm \operatorname{SEM}(n=3) .{ }^{*} P<0.05$ is significant difference compared to the negative control

\section{In vitro SOYBEAN LIPOXYGENASE (SBL) INHIBITORY ACTIVITY}

Among all extracts of the seven Ficus species, the crude methanol from the stem of $F$. aurantiaca, and $F$. parietalis, leaf of $F$. annulata, and $F$. obscura showed SBL inhibition with the $\mathrm{IC}_{50}$ values of $0.3,0.7,6.3$, and $53.2 \mu \mathrm{g} / \mathrm{mL}$, respectively. Meanwhile, the $\mathrm{IC}_{50}$ values of crude methanol from the stem of $F$. parietalis, and $F$. aurantiaca showed remarkable activities compared to standard drug phenidone with an $\mathrm{IC}_{50}$ value of 0.35 $\mu \mathrm{g} / \mathrm{mL}$. The phytochemical analysis of different species of Ficus showed the presence of flavonoids, coumarins, alkaloids, steroids, pentacyclic triterpenes, simple phenols, and salicylic acids (Cheng et al. 2019; Mawa et al. 2016). Meanwhile, the inhibition of lipoxygenase was mostly due to the attachment of the keto group. The percentage of inhibitions ( $\%$ ) and the $\mathrm{IC}_{50}$ values of active extracts with dose-dependent effects are shown in Figure 4 and Table 2, respectively. 


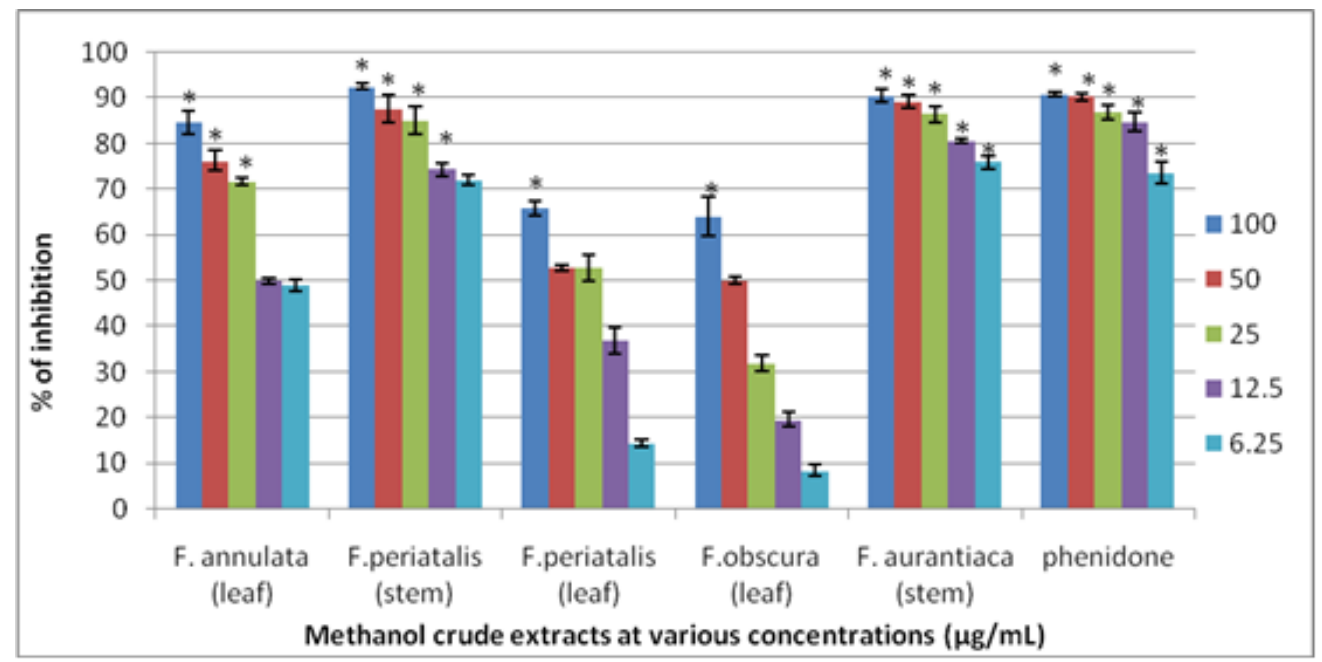

FIGURE 4. Soybean lipoxygenase inhibitory effects of active crude methanol

Data are mean $\pm \operatorname{SEM}(n=3)$. $* \mathrm{P}<0.05$ is significant difference compared to the negative control

TABLE 2. $\mathrm{IC}_{50}$ values of active crude methanol and positive control for soybean lipoxygenase and xanthine oxidase activity. Data represents mean $\pm \operatorname{SEM}(n=3)$ in triplicate measurement

\begin{tabular}{|c|c|c|c|}
\hline \multirow[t]{2}{*}{ Plant species } & \multirow[t]{2}{*}{ Parts } & \multicolumn{2}{|c|}{$\mathrm{IC}_{50}$ values $\pm \operatorname{SEM}(\mu \mathrm{g} / \mathrm{mL})$} \\
\hline & & $\begin{array}{l}\text { Soybean } \\
\text { lipoxygenase }\end{array}$ & Xanthine oxidase \\
\hline F. anuulata & leaf & $6.36 \pm 0.3$ & $8.90 \pm 0.4$ \\
\hline F. parietalis & leaf & $34.97 \pm 2.3$ & $22.08 \pm 0.2$ \\
\hline F. parietalis & stem & $0.71 \pm 0.1$ & $1.03 \pm 0.4$ \\
\hline F. aurantiaca & stem & $0.30 \pm 2.1$ & $0.90 \pm 0.8$ \\
\hline F. bengalgensis & leaf & - & $30.32 \pm 5.8$ \\
\hline F. obscura & leaf & $53.20 \pm 3.0$ & - \\
\hline F. grossularioidae & leaf & - & - \\
\hline F. heteropleura & leaf & - & - \\
\hline $\begin{array}{l}\text { Allopurinol } \\
\text { (positive control) }\end{array}$ & - & - & $0.96 \pm 0.3$ \\
\hline $\begin{array}{l}\text { Phenidone } \\
\text { (positive control) }\end{array}$ & - & $0.35 \pm 0.1$ & - \\
\hline
\end{tabular}




\section{CONCLUSION}

This report described biological screening for PMNs chemotaxis, ROS inhibitory activity of crude methanol extracts on human whole blood and PMNs, soybean lipoxygenase and xanthine oxidase enzyme inhibitory activities of specific species of Ficus. A total of seven Ficus species were extracted from different parts. Among all extracts, the crude methanol from the stem of $F$. aurantiaca and $F$. parietalis, and leaf of $F$. annulata showed strong inhibition in all assays. Crude methanol extracts from $F$. parietalis, $F$. aurantiaca, $F$. annulata, and $F$. obscura thus supported the phytochemical investigation and their ethnopharmacological properties for wound healing and inflammation. Therefore, $F$. aurantiaca (stem), F. parietalis (stem), and F. annulata (leaf) may be prospective source of new leads in the development of new immunomodulatory agents, as well as being functional as remedies in hyperuricaemia and gout. Additionally, this study can establish the source for exploring further the appropriate phytochemical investigation and drug improvement on other mechanisms of immunomodulatory responses.

\section{ACKNOWLEDGEMENTS}

This work was supported by the grant UKM-GGPMTKP-058-2010, UKM-Pharmacy-03-FRGS 00292010 and UKM-DIPM-006-2011. Special thanks to the Ministry of Higher Education Malaysia, for CSFP.

\section{REFERENCES}

Burkill, I.H. 1966. A Dictionary of the Economic Products of the Malay Peninsula. Kuala Lumpur: Ministry of Agriculture and Co-operatives.

Chen, X.L., Deng, Z.T., Huang, X.Y., Geng, Changan. \& Chen, J.J. 2018. Liquid chromatography-mass spectrometry combined with xanthine oxidase inhibition profiling for identifying the bioactive constituents from Cistanche deserticola. International Journal of Mass Spectrometry 430: 1-7.

Cheng, J., Zhang, B., Zhu, W., Zhang, C., Qin, Y., Abe, M., Akihisa, T., Liu, W., Feng, F. \& Zhang, J. 2019. Traditional uses, phytochemistry and pharmacology of Ficus hispida L.f.: A review. Journal of Ethnopharmacology 248: 112204.

Hiyoshi, H., Wangdi, T., Lock, G., Saechao, C., Raffatellu, M., Cobb, B.A. \& Bäumler, A.J. 2018. Mechanisms to evade the phagocyte respiratory burst arose by convergent evolution in typhoidal Salmonella serovars. Cell Reports 22(7): 17871797.

Kamaruddin, M.S. \& Latiff, A. 2002. Tumbuhan Ubatan Malaysia. Universiti Kebangsaan Malaysia, Selangor: Pusat Pengurusan Penyelidikan.

Khajuria, V., Gupta, S., Bhagat, A. \& Ahmed, Z. 2017. Invitro assessment of cytotoxicity, antioxidant and antiinflammatory activities of Ficus palmate. Journal of Herbal Medicine 13: 71-75.

Koko, W.S., Mesaik, M.A., Yousof, S., Galal, M. \& Choudary, M.I. 2008. In vitro immonumodulating properties of selected
Sudanese medicinal plants. Journal of Ethnopharmacology 118: 26-34

Lee, B., Jeong, H.H., Kang, K.K., Lee, C.S. \& Lee, S.H 2019. Improvement of diffusion-based microfluidic chemotaxis assay through stable formation of a chemical gradient. Chemical Engineering Science 202: 130-137.

Liu, F., Deng, C., Cao, W., Zeng, G., Deng, X. \& Zhou, Y. 2017. Phytochemicals of Pogostemon cablin (Blanco) Benth. aqueous extract: Their xanthine oxidase inhibitory activities. Biomedicine \& Pharmacotherapy 89: 544-548.

Mamat, N., Jamal, J.A., Jantan, I. \& Husain, K. 2014. Xanthine oxidase inhibitory and DPPH radical scavenging activities of some Primulaceae species. Sains Malaysiana 43(12): 1827-1833.

Mawa, S., Jantan, I. \& Husain, K. 2016. Isolation of terpenoids from the stem of Ficus aurantiaca Griff and their effects on reactive oxygen species production and chemotactic activity of neutrophils. Molecules 21: 9. DOI: 10.3390/ molecules21010009.

Mawa, S., Husain, K. \& Jantan, I. 2013. Ficus carica L. (Moraceae): Phytochemistry, traditional uses and biological activities. Evidence-Based Complementary and Alternative Medicine 2013: 974256.

Srivastava, P., Vyas, V.K., Variya, B., Patel, P., Qureshi, G. \& Ghate, M. 2016. Synthesis, anti-inflammatory, analgesic, 5-lipoxygenase (5-LOX) inhibition activities, and molecular docking study of 7-substituted coumarin derivatives. Bioorganic Chemistry 67: 130-138.

Yang, T.H., Yan, D.X., Huang, X.Y., Hou, B., Ma, Y.B., Peng, H. \& Geng, C.A. 2019. Termipaniculatones A-F, chalconeflavonone heterodimers from Terminthia paniculata, and their protective effects on hyperuricemia and acute gouty arthritis. Phytochemistry 164: 228-235.

Yang, Y., Zheng, K., Mei, W., Wang, Y., Yu, C., Yu, B. \& Hu, J. 2018. Anti-inflammatory and proresolution activities of bergapten isolated from the roots of Ficus hirta in an in vivo zebrafish model. Biochemical and Biophysical Research Communications 496(2): 763-769.

Yuandani, Menaga Ilangkovan, Ibrahim Jantan, Hazni Falina Mohamad, Khairana Husain \& Amirul Faiz Abdul Razak. 2013. Inhibitory effects of standardized extracts of Phyllanthus amarus and Phyllanthus urinaria and their maker compounds on phagocytic activity of human neutrophis. Evidence-Based Complementary and Alternative Medicine 2013: 603634. DOI: 10.1155/2013/603634.

Yuandani, Ibrahim Jantan, Menaga Ilangkovan, Khairana Husain \& Kok Meng Chan. 2016. Inhibitory effects of compounds from Phyllanthus amarus on nitric oxide production, lymphocyte proliferation and cytokine release from phagocytes. Drug Design, Development and Therapy 10: 1935-1945.

Zhang, Y.Y., Thakur, K., Wei, C.K., Wang, H., Zhang, J.G. \& Wei, Z.J. 2018. Evaluation of inhibitory activity of natural plant polyphenols on soybean lipoxygenase by UFLC-mass spectrometry. South African Journal of Botany 120: 179-185.

Shukranul Mawa \& Khairana Husain*

Drug \& Herbal Research Centre

Faculty of Pharmacy

Universiti Kebangsaan Malaysia

Jalan Raja Muda Abdul Aziz

50300 Kuala Lumpur, Federal Territory

Malaysia 
Ibrahim Jantan

School of Pharmacy

Taylor's University

Lakeside Campus

47500 Subang Jaya, Selangor Darul Ehsan

Malaysia
Fadzureena Jamaluddin

Forest Research Institute Malaysia (FRIM), Kepong

52109 Kuala Lumpur, Federal Territory

Malaysia

*Corresponding author; email: khairana@ukm.edu.my

Received: 10 May 2019

Accepted: 28 January 2020 